\title{
PERSEPSI PESERTA DIDIK TENTANG KOMPETENSI GURU TERHADAP HASIL BELAJAR
}

FERRY HANDS UMBU TAMU

SMA Negeri 2 Takari Kabupaten Kupang Nusa Tenggara Timur

Email : ferryumbutamu22@gmail.com

\begin{abstract}
ABSTRAK
Penelitian ini dilakukan karena diketahui dan ditemukan sejumlah peserta didik memperoleh nilai di bawah kriteria ketuntasan minimal mata pelajaran kelompok peminatan ilmu-ilmu sosial. Rumusan masalah dalam penelitian ini adalah bagaimana persepsi peserta didik tentang kompetensi guru terhadap hasil belajar peserta didik Kelas XI IIS SMA Negeri 2 Takari Tahun Pelajaran 2019/2020. Langkah atau tahapan dalam penelitian adalah dengan melakukan studi dokumentasi dan pengisian instrumen/kuesioner/angket penelitian. Populasi dalam penelitian ini berjumlah 36 orang, dengan sampel jenuh. Data hasil rekapan pengisian instrumen/kuesioner/angket penelitian yang diperoleh dianalisis secara statistik deskriptif. Hasil analisis statistik deskriptif ditemukan, bahwa persepsi peserta didik tentang kompetensi guru berada pada kategori 'cukup baik' (66\%) dan persepsi perseta didik terhadap hasil belajar pada kategori 'baik' (71\%). Fenomena sebenarnya menunjukkan bahwa lebih dari setengah bagian atau sebesar $80,55 \%$ peserta didik memberikan persepsi 'baik' tentang kompetensi guru. Berdasarkan hasil penelitian disarankan, agar kompetensi guru ditingkatkan dengan cara lebih giat mengikuti berbagai kegiatan pengembangan diri karena persepsi tentang kompetensi guru berpengaruh terhadap hasil belajar peserta didik.

Kata Kunci : Peserta Didik, Hasil Belajar, Kompetensi Guru
\end{abstract}

\section{PENDAHULUAN}

Hasil belajar sebagai perwujudan perubahan tingkah laku merupakan puncak dari suatu proses yang dilakukan dalam belajar, yaitu adanya peningkatan kemampuan peserta didik sesuai dengan tujuan yang ditetapkan. Bloom dalam Makmun, (2009: 167) menggolongkan hasil belajar dalam kawasan kognitif, afektif, dan psikomotorik. Aspek kompetensi yang dinilai meliputi kemampuan kognitif, psikomotorik, dan afektif, sesuai dengan Peraturan Pemerintah Nomor 19 Tahun 2005 Pasal 64 Rancangan Penilaian Hasil Belajar Kurikulum Tingkat Satuan Pendidikan yang dikembangkan Direktorat Pembinaan Sekolah Menengah Atas.

Penilaian hasil belajar oleh pendidik dilakukan secara berkesinambungan untuk memantau proses, kemajuan, dan perbaikan hasil dalam bentuk ulangan harian, ulangan tengah semester, ulangan akhir semester, dan ulangan kenaikan kelas. Kriteria ketuntasan minimal setiap mata pelajaran ditetapkan di awal tahun pelajaran berdasarkan Permendiknas No. 20 Tahun 2007 yang dijabarkan dalam Juknis Penetapan KKM di SMA (Depdiknas, 2010: 27). Berdasarkan studi dokumentasi, diketahui dan ditemukan bahwa sejumlah peserta didik memperoleh nilai di bawah kriteria ketuntasan minimal mata pelajaran. 


\section{Tabel 1. Rekapitulasi Nilai Ujian Semester Genap Peserta Didik Kelas XI IIS SMA} Negeri 2 Takari Tahun Pelajaran 2019/2020

\begin{tabular}{|c|c|c|c|c|c|}
\hline $\begin{array}{c}\text { Mata Pelajaran } \\
\text { Kelompok Peminatan }\end{array}$ & $\begin{array}{l}\text { Nilai } \\
\text { KKM }\end{array}$ & $\begin{array}{c}\text { Jumlah Peserta } \\
\text { Didik yang Tuntas }\end{array}$ & $\%$ & $\begin{array}{c}\text { Jumlah Peserta Didik } \\
\text { yang Tidak Tuntas }\end{array}$ & $\%$ \\
\hline Geografi & 80 & 14 & 38,89 & 22 & 61,11 \\
\hline Sejarah & 80 & 16 & 44,44 & 20 & 55,56 \\
\hline Sosiologi & 75 & 15 & 41,76 & 21 & 58,33 \\
\hline Ekonomi & 75 & 17 & 47,22 & 19 & 52,78 \\
\hline
\end{tabular}

Sumber: Wali Kelas XI IIS (2019).

Tabel 1 menggambarkan adanya masalah, sebagai salah satu bentuk hasil belajar. Hal ini sangat penting untuk diketahui dan menemukan faktor-faktor yang mempengaruhinya. Oleh karena itu, masalah hasil belajar menjadi menarik untuk diteliti dan ditetapkan sebagai variabel terikat dalam penelitian ini. Hasil belajar sangat dipengaruhi oleh faktor dalam diri peserta didik (intern) dan faktor dari luar diri peserta didik (ekstern). Hal ini didukung oleh Clark dalam Sabri, (2005: 25) yang menyatakan bahwa 70\% hasil belajar siswa di sekolah dipengaruhi oleh kemampuan siswa dan $30 \%$ dipengaruhi lingkungan.

Faktor dari dalam peserta didik yang berpengaruh terhadap hasil belajar di antaranya inteligensi, minat belajar, bakat, usaha, motivasi, perhatian, kelemahan, dan kesehatan. Selain itu, faktor dari luar diri peserta didik yang mempengaruhi hasil belajar di antaranya lingkungan fisik dan non fisik termasuk suasana kelas dalam belajar, riang gembira, menyenangkan, lingkungan sosial budaya, lingkungan keluarga, program sekolah termasuk komite sekolah, kompetensi guru, sarana pendidikan dan teman sekolah. Berdasarkan identifikasi faktor-faktor yang mempengaruhi hasil belajar terdapat faktor dominan yang mempengaruhi hasil belajar, yaitu kompetensi guru. Fenomena faktor dominan tersebut tergambar dari adanya tenaga pendidik yang belum memiliki sertifikat pendidik.

Kompetensi guru sebagai salah satu faktor instrumental dari luar diri peserta didik kaitan erat dengan kemampuan (ability). Battlow dalam Djaelani, (2010: 44) menyatakan bahwa kompetensi guru (teacher competence) adalah the ability of a teacher to responsibly perform his or her duties appropriately. (Artinya, kompetensi guru merupakan kemampuan seorang guru dalam melaksanakan kewajiban-kewajibannya secara wajar). Kompetensi guru merupakan kemampuan dan kewenangan dalam melaksanakan profesi keguruanya. Profesi memerlukan kemampuan dan keahlian khusus dalam melaksanakan pekerjaannya. Pekerjaan profesi hanya dapat dilakukan oleh mereka yang khusus dipersipakan untuk itu. Penguasaan kompetensi guru secara nyata dalam menjalankan tugas dan pekerjaanya menjadi tuntutan profesionalisme.

Oleh karena itu, kompetensi yang telah dikuasai guru akan lebih dituntut aktualisasinya dalam hubungan dengan proses dan hasil belajar. Keberadaan guru memang diperlukan dan pada kenyataannya berpengaruh terhadap proses dan hasil belajar. Akan tetapi peserta didik yang belajar di sekolah yang sama belum tentu mendapatkan hasil belajar yang sama karena dipengaruhi faktor lain. Salah satunya adalah kompetensi guru. Kompetensi guru diperlukan untuk mengembangkan proses dan hasil belajar peserta didik. Hal ini berguna dalam upaya menunjukkan pencapaian harapan yang dicita-citakan, yaitu hasil belajar. Selain itu berguna pula untuk penerapan pola dan model pembelajaran, sikap, kepribadian, dan intelegensi serta menjadi suri teladan. Kompetensi guru yang tinggi akan lebih mampu menciptakan lingkungan belajar di kelas yang aktif, kreatif, efektif, dan menyenangkan, serta akan lebih mampu mengelola kelasnya sehingga proses dan hasil belajar peserta didik berada pada tingkat optimal.

Hal itu sangat berbeda dengan kompetensi guru yang rendah. Rendahnya kompetensi guru yang dimiliki berakibat pada kurang mampu mengelola proses belajar yang efektif di kelas, sehingga hasil belajar tidak maksimal. Kurang efektifnya proses belajar disebabkan guru belum profesional. Guru Profesional berarti memiliki sertifikat profesi sebagai pendidik. Sertifikat 
pendidik adalah bukti formal sebagai pengakuan yang diberikan kepada guru dan dosen sebagai tenaga profesional (Pasal 1 ayat 12 UU No. 14 Tahun 2005).

Berdasarkan studi dokumentasi tentang pembagian tugas mengajar guru mata pelajaran yang mengajar diperoleh data sebagai berikut:

Tabel 2. Rekapitulasi Guru Mata Pelajaran Yang Mengajar Peserta Didik Kelas XI IIS SMA Negeri 2 Takari Tahun Pelajaran 2019/2020.

\begin{tabular}{ccc}
\hline $\begin{array}{c}\text { Guru Mata Pelajaran } \\
\text { Yang Mengajar Peserta Didik }\end{array}$ & Kelas XI IIS & $\%$ \\
\hline Belum sertifikasi & 3 & 75,00 \\
\hline Sudah sertifikasi & 1 & 25,00 \\
\hline
\end{tabular}

Tabel 2 memberikan gambaran bahwa masih terdapat guru yang belum memiliki sertifikat pendidik, sehingga dapat disimpulkan bahwa guru mata pelajaran sebagai tenaga profesional berkaitan erat dengan kompetensi guru sebagai salah satu faktor yang mempengaruhi hasil belajar. Hal ini sangat penting untuk diketahui dan ditemukan pengaruhnya. Oleh karena itu, kompetensi guru menjadi menarik untuk diteliti dan ditetapkan sebagai salah satu variabel bebas dalam penelitian ini.

Berdasarkan latar belakang tersebut, ditemukan masalah dalam hasil belajar yang diduga dipengaruhi oleh kompetensi guru. Oleh karena itu, penulis tertarik untuk melakukan penelitian dengan rumusan masalah Bagaimana Persepsi Peserta Didik tentang Kompetensi Guru terhadap Hasil Belajar yang bertujuan untuk mengetahui Persepsi Peserta Didik tentang Kompetensi Guru terhadap Hasil Belajar. Secara teoritis hasil penelitian ini diharapkan dapat memberi sumbangan pemikiran tentang Pengaruh Persepsi Peserta Didik tentang Kompetensi Guru terhadap Hasil Belajar dan secara praktis hasil penelitian ini sebagai bahan informasi tambahan bagi pelaku pendidikan dalam mengambil kebijakan untuk meningkatkan hasil belajar.

\section{METODE PENELITIAN}

Penelitian ini adalah penelitian eksplanatif (explanative reseach). Penelitian eksplanatif ditujukan untuk memberikan penjelasan tentang hubungan antar fenomena atau variabel. Penelitian ekplanatif mencoba mencari kejelasan hubungan antar hal tersebut. Hubungan tersebut bisa berbentuk hubungan korelasi atau saling hubungan, sumbangan atau kontribusi satu variabel terhadap variabel lainnya ataupun hubungan sebab akibat (Sukmadinata, 2010: 20).

Instrumen penelitian adalah daftar peryataan yang digunakan untuk mengumpulkan data dengan menggunakan skala likert. Variabel penelitian yang dikumpulkan akan dijabarkan menjadi dimensi, dimensi dijabarkan menjadi sub variabel kemudian sub variabel dijabarkan lagi menjadi indikator-indikator yang dapat diukur. Akhirnya indikator-indikator yang terukur dapat dijadikan titik tolak untuk membuat item instrumen yang berupa pernyataan atau pertanyaan yang perlu dijawab oleh responden (Riduwan, 2014: 38-39).

Setiap jawaban dihubungkan dengan bentuk pernyataan atau dukungan sikap yang diungkapkan dengan kata-kata sebagai berikut: pernyataan positif, Sangat Setuju (SS) = 5, Setuju $(\mathrm{S})=4$, Netral $(\mathrm{N})=3$, Tidak Setuju $(\mathrm{TS})=2$, dan Sangat Tidak Setuju $($ STS $)=1$. Sedangkan pernyataan negatif, Sangat Setuju $(S S)=1$, Setuju $(S)=2$, Netral $(N)=3$, Tidak Setuju $(T S)=4$, dan Sangat Tidak Setuju (STS) = 5 (Riduwan, 2014: 39).

Dalam penelitian ini terdapat dua variabel yakni satu variabel bebas (X) yaitu kompetensi guru dan satu variabel terikat (Y) yaitu hasil belajar. Kompetensi guru adalah kemampuan penguasaan pengetahuan, keterampilan dan sikap yang mengarah pada pencapaian tujuan dalam melaksanakan keprofesionalan. Sedangkan hasil belajar adalah perubahan perilaku setelah mengikuti proses belajar pada aspek kognitif. Pengukuran variabel dilakukan dengan cara 
menetapkan variabel, sub variabel, indikator, item pernyataan, dan skala pengukuran yang sebagaimana disajikan dalam tabel.

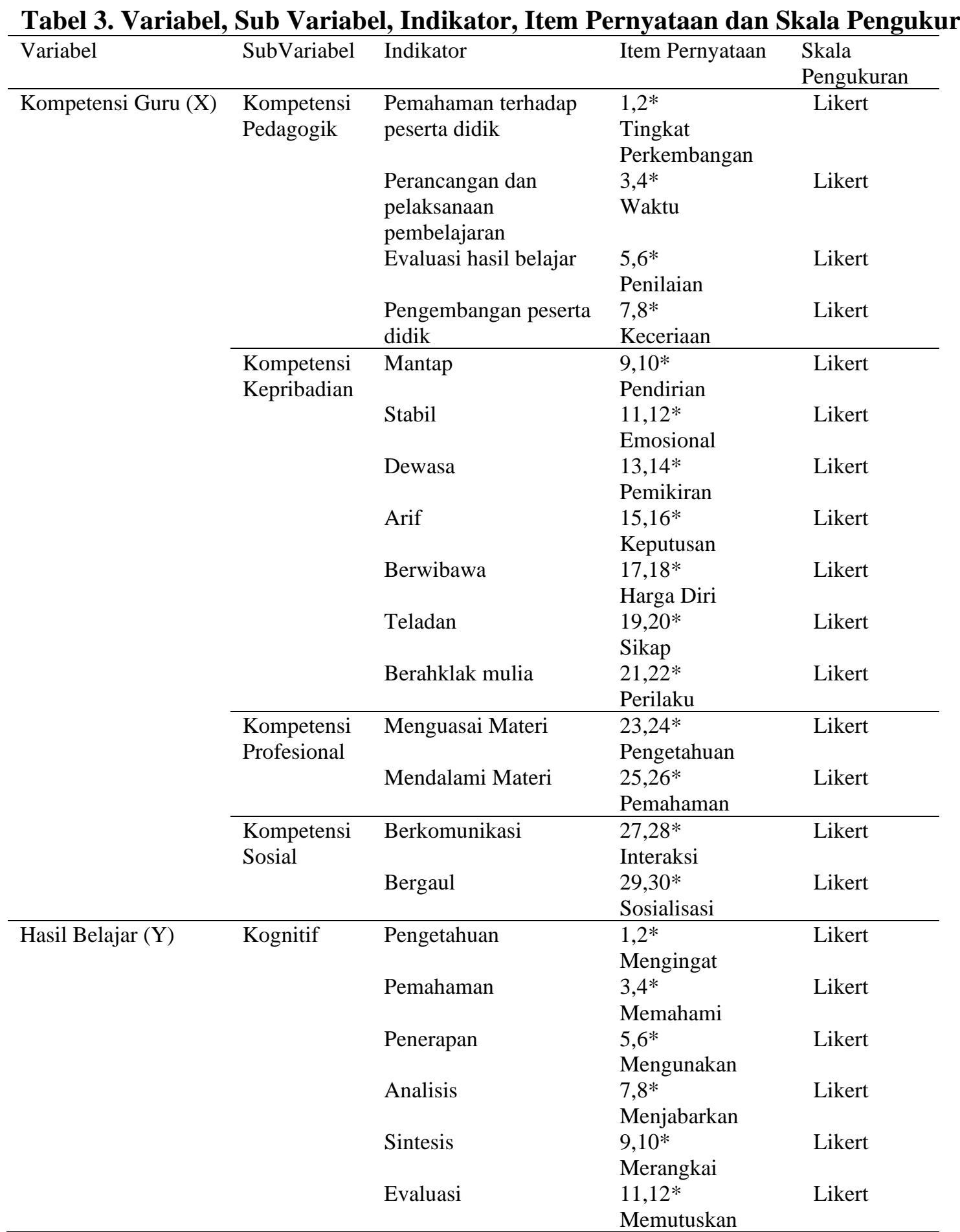

Sumber: Instrumen / Kuesioner / Angket Penelitian (2019).

Keterangan: * Butir pernyataan negatif

Statistik yang digunakan untuk menganalisis data dengan cara mendeskripsikan atau menggambarkan data yang telah dikumpul sebagaimana adanya tanpa bermaksud membuat kesimpulan yang berlaku untuk umum atau generalisasi. Statistik deskriptif dapat digunakan bila peneliti hanya ingin mendeskripsikan data sampel, dan tidak ingin membuat kesimpulan yang berlaku untuk populasi dimana sampel diambil (Sugiyono, 2014: 238-239). 
Untuk menguraikan atau menggambarkan atau menyatakan karakteristik bagaimana persepsi responden terhadap masing-masing variabel digunakan rumus (Levis, 2013: 173) sebagai berikut:

$$
P S_{-p}=\left(\frac{\bar{X} P s_{-p}}{5}\right) \times 100 \%
$$

Keterangan:

$P S_{-p}=$ Kategori Persepsi Responden Populasi

$\bar{X} P s_{-p}=$ Rata-Rata Skor Untuk Persepsi Populasi

$5=$ Berasal Dari Skor Tertinggi Skala Likert

Untuk menentukan kategori persepsi populasi responden, hasil perhitungan dikategorikan dengan persentase pencapaian skor maksimum (Levis, 2013: 162) sebagai berikut:

$\geq 20 \%-36 \%=$ Sangat Tidak Baik/Sangat Rendah

$>36 \%-52 \%=$ Tidak Baik/Rendah

$>52 \%-68 \%=$ Cukup Baik/Cukup Tinggi

$>68 \%-84 \%=$ Baik/Tinggi

$>84 \%-100 \%=$ Sangat Baik/Sangat Tinggi

\section{HASIL DAN PEMBAHASAN}

\section{Hasil}

Karakteristik responden adalah keadaan atau identitas yang melekat pada responden. Karakteristik responden menyangkut berbagai aspek yang melatarbelakangi responden dalam memberikan pendapat. Karakteristik responden berdasarkan jenis kelamin tidak dapat dihindari. Laki-laki dan perempuan mempunyai kesempatan yang sama dalam mendapatkan pendidikan yang layak. Jumlah responden laki-laki lebih sedikit dari responden perempuan. Oleh karena itu, jawaban responden terhadap variabel penelitian memberikan hasil yang berbeda. Bahwa usia responden paling banyak antara 16-18 tahun. Pada kondisi usia ini, memang sesuai dengan usia sekolah di SMA. Oleh karena itu, jawaban responden terhadap variabel penelitian bervariasi dan dapat dipertanggungjawabkan.

Hasil analisis statistik deskriptif hanya memberikan gambaran terhadap setiap variabel berdasarkan data yang terkumpul melalui kuesioner yang merupakan jawaban responden atas pernyataan terhadap variabel yang diteliti. Analisis data hasil penelitian variabel kompetensi guru (X) menunjukkan bahwa skor rata-rata yang diperoleh dari persepsi atau jawaban responden tentang variabel kompetensi guru (X) sebagaimana disajikan pada Tabel 4

Tabel 4. Rekapitulasi Analisis Hasil Perolehan Skor Rata-Rata Persepsi Responden Tentang Variabel Kompetensi Guru (X)

\begin{tabular}{|c|c|c|c|c|c|c|c|c|}
\hline \multirow[b]{2}{*}{ Responden } & \multirow[b]{2}{*}{$\begin{array}{c}\text { Item } \\
\text { Pernyataan }\end{array}$} & \multicolumn{2}{|c|}{ Skor Maksimum } & \multicolumn{2}{|c|}{ Skor Perolehan } & \multirow{2}{*}{$\begin{array}{c}\text { Skor } \\
\text { Rata- } \\
\text { rata } \\
\bar{X} P s_{-p}\end{array}$} & \multirow{2}{*}{$\begin{array}{c}\% \\
\text { Pencapaian } \\
\text { Skor } \\
\text { Maksimum } \\
P s_{-p} \\
\end{array}$} & \multirow[b]{2}{*}{ Kategori } \\
\hline & & Tertinggi & Terendah & Tertinggi & Terendah & & & \\
\hline 36 & 30 & 150 & 30 & 118 & 75 & 3,3 & 66 & $\begin{array}{c}\text { Cukup } \\
\text { Baik }\end{array}$ \\
\hline
\end{tabular}

Sumber: Hasil Analisis Data Penelitian (2019).

Tabel 4 menunjukkan bahwa perolehan skor tertinggi 118 dan skor terendah 75 . Hal ini berarti skor yang diperoleh berada dalam batasan yang diharapkan dari variabel kompetensi guru (X) dengan skor tertinggi 150 dan skor terendah 30. Skor rata-rata yang diperoleh dari persepsi 
atau jawaban responden tentang variabel kompetensi guru (X) adalah sebesar 3,3. Persentase pencapaian skor maksimum sebesar $(3,3 / 5 \times 100)=66 \%$. Nilai $66 \%$ termasuk dalam kategori “cukup baik" yaitu pada skor maksimum > 52-68. Oleh karena itu, dideskriptifkan bahwa ratarata responden mempunyai persepsi “cukup baik" terhadap kompetensi guru (X).

Analisis data hasil penelitian variabel hasil belajar (Y) menunjukkan bahwa skor rata-rata yang diperoleh dari persepsi atau jawaban responden tentang variabel hasil belajar (Y) sebagaimana disajikan pada Tabel 5

Tabel 5. Rekapitulasi Analisis Hasil Perolehan Skor Rata-Rata Persepsi Responden Tentang Variabel Hasil Belajar (Y)

\begin{tabular}{|c|c|c|c|c|c|c|c|c|}
\hline \multirow[b]{2}{*}{ Responden } & \multirow[b]{2}{*}{$\begin{array}{c}\text { Item } \\
\text { Pernyataan }\end{array}$} & \multicolumn{2}{|c|}{ Skor Maksimum } & \multicolumn{2}{|c|}{ Skor Perolehan } & \multirow{2}{*}{$\begin{array}{c}\text { Skor } \\
\text { Rata- } \\
\text { rata } \\
\bar{X} P S_{-p}\end{array}$} & \multirow{2}{*}{$\begin{array}{c}\% \\
\text { Pencapaian } \\
\text { Skor } \\
\text { Maksimum } \\
P s_{-p}\end{array}$} & \multirow[b]{2}{*}{ Kategori } \\
\hline & & Tertinggi & Terendah & Tertinggi & Terendah & & & \\
\hline 36 & 12 & 60 & 12 & 54 & 29 & 3,5 & 71 & Baik \\
\hline
\end{tabular}

Sumber: Hasil Analisis Data Penelitian (2019).

Tabel 5 menunjukkan bahwa perolehan skor tertinggi 54 dan skor terendah 29. Hal ini berarti skor yang diperoleh berada dalam batasan yang diharapkan dari variabel hasil belajar (Y) dengan skor tertinggi 60 dan skor terendah 12. Skor rata-rata yang diperoleh dari persepsi atau jawaban responden tentang variabel hasil belajar (Y) adalah sebesar 3,5. Persentase pencapaian skor maksimum sebesar $(3,5 / 5 \times 100)=71 \%$. Nilai $71 \%$ termasuk dalam kategori "baik" yaitu pada skor maksimum > 68-84. Oleh karena itu dideskriptifkan bahwa rata-rata responden mempunyai persepsi "baik" terhadap hasil belajar (Y).

\section{Pembahasan}

Hasil analisis statistik deskriptif menunjukkan bahwa persepsi tentang kompetensi guru dikategorikan 'cukup baik'. Hal ini terlihat dari persentase pencapaian skor maksimum sebesar $66 \%$. Pencapaian ini menggambarkan persepsi atau jawaban responden tentang kompetensi guru terhadap hasil belajar berada pada tingkat yang diharapkan. Fenomena yang sebenarnya terjadi menunjukkan bahwa lebih dari setengah bagian atau sebanyak 80,55\% peserta didik memiliki penilaian atau persepsi baik tentang kompetensi guru. Peserta didik merasa guru baik dalam mengajar sesuai materi dengan tingkat kemampuan dan perkembangan peserta didik, merencanakan dan melaksanakan pembelajaran tepat waktu, melaksanakan evaluasi sesuai tujuan pembelajaran, dan menumbuhkan keceriaan peserta didik dalam pembelajaran. Selain itu peserta didik merasa guru baik dalam menunjukkan pendirian yang mantap, stabil mengendalikan emosi, dewasa, arif, berwibawa, teladan, dan berahklak mulia terhadap pembelajaran peserta didik. Selanjutnya guru baik dalam menguasai materi dan mendalami terhadap pembelajaran peserta didik. Lebih lanjut peserta didik merasa guru baik dalam berkomunikasi secara santun, bergaul secara baik dalam pembelajaran dengan peserta didik. Hal ini berimplikasi positif untuk mendukung tecapainya hasil belajar secara maksimal sesuai tujuan pembelajaran yang ingin dicapai.

Hasil penelitian ini sejalan dengan Syah dalam Djaelani (2010: 70) yang menyatakan bahwa kompetensi adalah kemampuan atau kecakapan. Senada dengan Syaodih dalam Satori, dkk, (2011: 2.2) yang menyatakan bahwa kompetensi adalah performan yang mengarah kepada pencapaian tujuan secara tuntas menuju kondisi yang diinginkan. Lebih lanjut UU No. 14 tahun 
2015 tentang Guru dan Dosen Bab I pasal 1 ayat 10 menyatakan bahwa kompetensi adalah seperangkat pengetahuan, ketrampilan, dan perilaku yang harus dimiliki, dihayati dan dikuasai oleh guru dalam melakasanakan keprofesionalan.

Berdasarkan pendapat diatas maka dapat disimpulkan bahwa kompetensi guru adalah kemampuan penguasaan pengetahuan, ketrampilan dan sikap yang mengarah pada pencapaian tujuan dalam melaksanakan keprofesionalan. Dengan demikian maka kompetensi mempunyai pengaruh yang besar untuk mencapai hasil belajar secara maksimal sesuai tujuan kognitif yang diharapkan. Hasil penelitian ini sejalan dengan penjelasan Peraturan Pemerintah Nomor 19 Tahun 2005 tentang Guru dan Dosen pasal 10 ayat (1) kompetensi guru meliputi kompetensi pedagogik, kompetensi kepribadian, kompetensi professional, dan kompetensi sosial yang diperoleh melalui pendidikan profesi. Hasil penelitian ini mendukung penelitian Rifa'i (2014) dan Marina (2014) yang menyimpulkan bahwa kompetensi guru berpengaruh signifikan terhadap hasil belajar.

\section{KESIMPULAN}

Berdasarkan hasil penelitian dan pembahasan maka dapat disimpulkan bahwa hasil analisis statistik deskriptif menunjukkan persentase pencapaian skor maksimum variabel kompetensi guru (X) sebesar 66\% (kategori persepsi 'cukup baik'), dan variabel hasil belajar (Y) sebesar 71\% (kategori persepsi 'baik'). Ini berarti kompetensi guru sesuai yang diharapkan. Hal ini menunjukkan bahwa masih ada persepsi lain yang menjadi faktor terhadap hasil belajar. Persepsi terhadap faktor lain ini yang perlu di selidiki dan dikembangkan lagi.

Berdasarkan kesimpulan hasil penelitian dan kaitannya dengan kegunaan penelitian ini maka dapat disarankan bahwa hendaknya guru dapat meningkatkan kompetensi diri melalui berbagai kegiatan pengembangan diri meliputi, penulisan karya ilmiah, pendidikan dan pelatihan, seminar, workshop, simposium, diskusi panel, IHT, TOT, dan MGMP. Dengan demikian peningkatan kompetensi guru dapat meningkatkan hasil belajar peserta didik.

\section{DAFTAR PUSTAKA}

Depdiknas. 2010. Juknis Penetapan KKM di SMA. Jakarta: Direktorat Pembinaan SMA

Djaelani. 2010. Etika dan Profesi Guru. Jakarta: Multi Kreasi Satudelapan.

Levis. 2013. Metode Penelitian Perilaku Petani. Maumere: Penerbit Ledalero.

Makmun. 2009. Psikologi Kependidikan Perangkat Sistem Pengajaran Modul. Bandung: PT. Rosda Karya.

Marina. 2014. Pengaruh Persepsi Siswa tentang Disiplin Guru dan Kompetensi Guru Terhadap Hasil Belajar Siswa pada Mata Pelajaran Akuntansi Kelas X di SMK Negeri 2 Padang. (http://www.jurnal.stikip.pgri.ac.id), diakses 23-09-2019.

Peraturan Pemerintah Nomor 19 Tahun 2005 tentang Standar Nasional Pendidikan. Jakarta: Depertemen Pendidikan Nasional Republik Indonesia.

Riduwan. 2004. Metode dan Teknik Menyusun Tesis. Bandung: Alfabeta.

Rifa'i. 2014. Pengaruh Pemanfaatan Perpustakaan Sekolah, Budaya Membaca, Kompetensi Guru, Terhadap Hasil Belajar Ekonomi. (http://www.jurnal.unila.ac.id), diakses tanggal 21-09-2019.

Sabri. 2005. Strategi Belajar Mengajar. Jakarta: Quantum Teaching.

Sugiyono. 2014. Metode Penelitian Manajemen. Bandung: Alfabeta.

Sukmadinata. 2010. Metode Penelitian Pendidikan. Bandung: Remaja Rosdakarya.

Undang-Undang Nomor 14 Tahun 2005 tentang Guru dan Dosen. Jakarta: Depertemen Pendidikan Nasional Republik Indonesia. 